\title{
NURSES' KNOWLEDGE AND PRACTICES ABOUT ORAL MUCOSITIS OF CANCER PATIENTS UNDERGOING CHEMOTHERAPY IN SULAIMANI CITY/IRAQ
}

\author{
Hassan Husien Abdalla ${ }^{1}$, Hadeel Abdulelah Ibrahim 2 * \\ 1. Department of adult nursing, College of Nursing, University of Sulaimani, City of Sulaimani, Iraq; \\ 2. Department of fundamentalsnursing, College of Nursing, University of Sulaimani, City of Sulaimani, Iraq. \\ Corresponding author: Hadeel Abdulelah Ibrahim \\ Email: hadeel.ibrahim@univsul.edu.iq
}

ORCID

\begin{abstract}
Oral health care is a crucial aspect of oncology nursing practice; therefore, this study was conducted to evaluate oncology nurses' knowledge and practice with oral mucositis (OM) of cancer patients undergoing chemotherapy. One hundred nurses were participated from Hiwa and Shahid Shaswari Garmian hospitals, in addition to a demographic, a questionnaire was designed and constructed by the researcher to assess the nurse's knowledge and practice through the mucositis undergoing chemotherapy. The mean age of participants was $32.15 \pm 7.63$ years, $53 \%$ of nurses were males $67 \%$ of them held a Diploma degree in nursing, while $55 \%$ had (1-5) years of experience in oncology field. in addition to $(78 \%)$ of participants lived in Sulaimaniah city. Finally, $84 \%$ of the participants received education program regarding oral mucositis. The Oncology nurses had good levels of knowledge in topics related to anatomy of oral cavity (64\%), Pathology of oral cavity with oral mucositis patients (73.59\%) and a significant differences were found between Nurses practice on mucositis of oral cavity and age, level of academic qualification, years of experience in oncology field and nurses were received education program regarding oral mucositis $(p<0.05)$. Good levels of Nurses' knowledge directly affected on good level of their Practice.
\end{abstract}

Keywords: Knowledge, Medical oncology, Nurses, Questionnaire. Oral mucositis

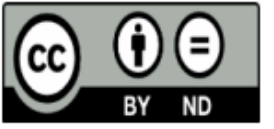

This work is licensed under a Creative Commons Attribution Non-Commercial 4.0 International License.

Received: 03 September 2021, Accepted: 15 December 2021, Available online: 20 January 2022 


\section{INTRODUCTION}

Global cancer estimates of cancer incidence and mortality suggest that there will be an estimated 18.1 million new cancer cases $(17.0$ million excluding non-melanoma skin cancer) and 9.6 million cancer deaths (9.5 million excluding nonmelanoma skin cancer) in 2018 (Bray et al., 2018). Patients diagnosed with cancer undergo different treatment modalities, including chemotherapy, radiotherapy, surgery, and bone marrow transplantation. As a result, they experience a wide range of long- and short-term complications, such as oral complications (Coolbrandt et al., 2018). Oral complications affect the quality of life, hold up treatment plans, delay cancer treatment in terms of dosage reduction and altered nutrition, and cause severe pain ( Southern, 2007) .

Oral mucositis $(O M)$ is a painful inflammatory, often ulcerative condition; and is a distressing acute side effect of cancer therapy (Tranmer et al., 2013). The complication usually start at 3-5 days after the first dose of chemotherapy and reaches its peak within 14 days (Suminski et al., 2017).

Despite the availability of various guidelines for OM management, their effect on clinical practice is limited. The actual care provided by nurses to patients with or without risk of OM is unclear. This inconsistency in care is due to the lack of knowledge and skills among oncology nurses in relation to $\mathrm{OM}$ guidelines and evidenced-based practices (Kanagalingam et al., 2018; Abu Sharour, 2019).

Nurses have a significant role in preventing and managing $\mathrm{OM}$ and decreasing its adverse effect on patients' health status. Their role, including conducting frequent oral assessment, patient education, and implementing oral care, has been acknowledged as an important factor in the treatment plan for OM (Sung et al., 2014) . However, nurses' practices and advice available for best practices are inconsistent. Improving nurses' knowledge and skills through continued training is required to improve oral care and minimize the risk of $\mathrm{OM}$. So this study was conducted to determine the nurses' knowledge and practice about oral mucositis in cancer patient undergoing chemotherapy .

\section{METHOD}

\section{-Study Design:}

This study was a quantitative -descriptive study conducted in Hiwa Oncology/Hematology Hospital and Shahid shaswari garmian hospital in
Sulaimaniyah city, Northern Iraq, from 12thOctober 2020 up to 10thOctober 2021.

\section{-Study Setting:}

One hundred nurses were participated from oncology units, including surgical, medical, hematological, pediatric, and adult clinics in Hiwa Oncology/Hematology hospital and Shahid Shaswari Garmian hospital in Sulaimaniyah city, while the rest of nurses in the same hospitals refused to participate. A demographic data related to the participants' gender, age, job title, level of academic qualification, experience, hours of education about OM, a questionnaire was designed and constructed by the researcher to assess the nurse's knowledge and practice through the mucositis undergoing chemotherapy. The study instruments composed of a Knowledge related to Anatomy of oral cavity (Tranmer et al., 2013) questions, pathology (Worthington et al., 2007) questions, general OM information (Pai and Ongole, 2015) questions and Nurse's practice (Kanagalingam et al., 2018) questions. The test included comprehension, understanding, application, and analysis-level questions. These questions mixed from related textbooks, guidelines, and the literature. Mosby's Oncology Nursing Advisor: A Comprehensive Guide to Clinical Practice (2016) was used to develop the questions for the test (Newton et al., 2016). The Oral Care Guidance and Support by the European Oral Care in Cancer Group (2018) was used as the scale (Al Ibraheemi and Shamoun, 2016; EOCC, 2018).

\section{Statistical analysis}

The collected data were compiled and analysed using percentages, mean, median, and Chi-square tests using SPSS version 21. P values of 0.05 were used as a cut-off point for the significance of the statistical test.

\section{RESULTS}

The findings in Table (1) shows that one hundred oncology nurses participated in the study. The mean age was $32.15 \pm 7.63$ years, $53 \%$ of nurses were males and $47 \%$ were females. The majority of the participants held a Diploma degree in nursing $(67 \%)$. with $55 \%$ had $(1-5)$ years of experience in oncology field. in addition to $(78 \%)$ of participants lived in Sulaimaniah city. Finally, $84 \%$ of the participants received education program regarding oral mucositis.

Table (2) evaluated the Oncology nurses' level of knowledge, including knowledge about anatomy, pathology of oral cavity and General oral mucositis information (definition, assessment, 
scoring, and treatment). The Oncology nurses had good levels of knowledge in topics related to anatomy of oral cavity (64\%), Pathology of oral cavity with oral mucositis patients(73.59\%) and General Oral mucositis information were (62.91\%).

There were statistically significant differences between mean of nurses' knowledge for anatomy of oral cavity and level of academic qualification $(p=0.003)$, years of experience in oncology field $(p=0.046)$. But, there were no statistically significant differences between knowledge for anatomy of oral cavity and age $(\mathrm{p}=0.101)$, gender $(p=0.641)$, residency $(p=0.285)$ in addition to those had received education program regarding oral mucositis $(p=0.182)$ as shown in table (3).

Table (4) illustrates that there were a statistically significant association between nurses' knowledge of pathology of oral cavity with oral mucositis patients and nurses who had received education program regarding oral mucositis $(p=0.49)$, level of academic qualification $(p=0.025)$ and Years of experience in oncology field $(p=0.001)$. But there were no significant association between nurses' knowledge of pathology of oral cavity with oral mucositis patients and age $(p=0.11)$, residency $(p=0.21)$ and gender $(p=0.722)$.

Table (5) revealed that a significant differences were found between mean of nurses' knowledge for general oral mucositis information and age $(p=0.023)$, level of academic qualification $(p=0.016)$,years of experience in oncology field $(p=0.01)$, in addition to those had received education program regarding oral mucositis $(p=0.046)$. But, there were no statistically significant differences between mean of knowledge for general oral mucositis information and gender $(p=0.69)$ neither residency $(p=0.762)$.

Table (6) reveals that the proportion on advice the patients to brush the teeth by using soft brush was greatest $(91 \%)$, encouraging the patients to use soft diet after chemotherapy was the second highest proportion $(88 \%)$, while $66 \%$ of nurse advice the patients to brush teeth twice a day and brush teeth more than two minutes each time.more than half (64\%) gave advice for patient's Proper dental checkup before and after chemotherapy, and just $14 \%$ of nurses advice the patients to oral cryotherapy (ice bag) for 30 minutes before bolus 5 -fluorouracil chemotherapy to prevent oral mucositis.

Table (7) shows that, there were statistically significant differences between Nurses practice on mucositis of oral cavity and age $(p=0.024)$, level of academic qualification ( $p=0.037)$, years of experience in oncology field $(p=0.001)$ and nurses were received education program regarding oral mucositis $(p=0.017)$. But, there were no statistically significant differences between nurses practice on mucositis of oral cavity and gender $(p=0.225)$, or residency $(p=0.982)$.

Table (8) was noted that a significant positive statistical correlation between (Nurses practice and knowledge for anatomy, nurses' knowledge of general oral mucositis information and knowledge for pathology) which is $(0.71,0.724$ and 0.575$)$ respectively, that the $(p$-values $=0.000)$.

\begin{tabular}{|c|c|c|c|}
\hline Variables & & Frequency & $\%$ \\
\hline \multirow{3}{*}{ Age/years } & $<25$ & 12 & 12.0 \\
\hline & $25-35$ & 66 & 66.0 \\
\hline & $35 \leq$ & 22 & 22.0 \\
\hline & Mean \pm S.D $32.15 \pm 7.63$ & & \\
\hline \multirow[t]{2}{*}{ Gender } & Male & 53 & 53.0 \\
\hline & Female & 47 & 47.0 \\
\hline \multirow{3}{*}{$\begin{array}{l}\text { Level of academic } \\
\text { qualification }\end{array}$} & $\begin{array}{c}\text { Preparatory nursing } \\
\text { school }\end{array}$ & 2 & 2.0 \\
\hline & Diploma degree & 67 & 67.0 \\
\hline & Bachelor degree & 26 & 26.0 \\
\hline \multirow{5}{*}{$\begin{array}{l}\text { Years of experience in } \\
\text { oncology field }\end{array}$} & Postgraduate degree & 5 & 5.0 \\
\hline & $1-5$ & 55 & 55.0 \\
\hline & $6-10$ & 35 & 35.0 \\
\hline & $11-15$ & 7 & 7.0 \\
\hline & $\begin{array}{c}\geq 16 \\
\text { Mean } \pm \text { S.D } 5.98 \pm 3.889\end{array}$ & 3 & 3.0 \\
\hline \multirow[t]{2}{*}{ Residency } & Outside city & 22 & 22.0 \\
\hline & Inside city & 78 & 78.0 \\
\hline \multirow{2}{*}{$\begin{array}{lr}\text { Had received } & \text { an } \\
\text { education } & \text { program } \\
\text { regarding } & \text { oral } \\
\text { mucositis } & \end{array}$} & Yes & 84 & 84.0 \\
\hline & No & 16 & 16.0 \\
\hline Total & & 100 & 100 \\
\hline
\end{tabular}


Table 2. Result of Nurses knowledge test sub- items.

\begin{tabular}{lccc}
\hline Test sub-items & $\begin{array}{c}\text { Right answer } \\
\mathbf{N}(\%)\end{array}$ & $\begin{array}{c}\text { Wrong answer } \\
\mathbf{N}(\%)\end{array}$ & Mean \pm SD \\
\hline Anatomy of the oral cavity (Q1-4) & $256(64)$ & $144(36)$ & $2.44 \pm 0.69$ \\
Pathology (Q1-9) & $1986(73.59)$ & $714(26.41)$ & $1.74 \pm 0.2$ \\
General Oral mucositis information (Q1-11) & $692(62.91)$ & $408(37.09$ & $2.42 \pm 0.69$ \\
\hline
\end{tabular}

Table 3. Association between Socio demographic characteristics and mean of nurses' knowledge about anatomy of oral cavity.

\begin{tabular}{|c|c|c|c|c|}
\hline Variables & Items & $\mathbf{N}$ & Mean $\pm S . D$ & Significant Test \\
\hline \multirow{3}{*}{ Age } & $<25$ & 12 & $2.39 \pm 0.50$ & \multirow{3}{*}{$\begin{array}{c}F=2.35 \\
P-\text { value }=0.101\end{array}$} \\
\hline & $25-35$ & 66 & $2.41 \pm 0.31$ & \\
\hline & $35 \geq$ & 22 & $2.58 \pm 0.33$ & \\
\hline \multirow{2}{*}{ Gender } & Male & 53 & $2.46 \pm 0.34$ & \multirow{2}{*}{$\begin{array}{l}\text { T-Test }=-0.467 \\
\text { P-value }=0.641\end{array}$} \\
\hline & Female & 47 & $2.43 \pm 0.35$ & \\
\hline \multirow{4}{*}{ Level of academic qualification } & $\begin{array}{l}\text { Preparatory } \\
\text { nursing school }\end{array}$ & 2 & $1.88 \pm 0.54$ & \multirow[t]{4}{*}{$\begin{array}{c}F=4.943 \\
P \text {-value }=0.003\end{array}$} \\
\hline & Diploma degree & 67 & $2.42 \pm 0.33$ & \\
\hline & Bachelor's degree & 26 & $2.47 \pm 0.31$ & \\
\hline & $\begin{array}{l}\text { Postgraduate } \\
\text { degree }\end{array}$ & 5 & $2.85 \pm 0.23$ & \\
\hline \multirow{4}{*}{$\begin{array}{l}\text { Years of experience in oncology } \\
\text { field }\end{array}$} & $1-5$ & 53 & $2.38 \pm 0.39$ & \multirow{4}{*}{$\begin{array}{c}F=2.527 \\
\text { P-value }=0.046\end{array}$} \\
\hline & $6-10$ & 35 & $2.48 \pm 0.25$ & \\
\hline & $11-15$ & 9 & $2.69 \pm 0.25$ & \\
\hline & $\geq 16$ & 3 & $2.63 \pm 0.18$ & \\
\hline \multirow{2}{*}{ Residency } & inside city & 22 & $2.51 \pm 0.33$ & \multirow{2}{*}{$\begin{array}{c}\text { T-Test }=1.075 \\
\text { P-value }=0.285\end{array}$} \\
\hline & outside city & 78 & $2.42 \pm 0.35$ & \\
\hline \multirow{2}{*}{$\begin{array}{l}\text { Had received education program } \\
\text { regarding oral mucositis }\end{array}$} & Yes & 84 & $2.42 \pm 0.36$ & \multirow{2}{*}{$\begin{array}{l}\text { T-Test }=-1.343 \\
\text { P-value }=0.182\end{array}$} \\
\hline & No & 16 & $2.55 \pm 0.25$ & \\
\hline
\end{tabular}

Table 4. Association between Socio demographic characteristics and nurses' knowledge of Pathology of oral cavity with oral

\begin{tabular}{|c|c|c|c|c|c|c|c|}
\hline \multirow{3}{*}{ Socio-demographic } & & \multicolumn{4}{|c|}{ nurses' knowledge (Q1-Q27) } & \multicolumn{2}{|c|}{ Significant Test } \\
\hline & & \multicolumn{2}{|c|}{ Incorrect } & \multicolumn{2}{|c|}{ Correct } & \multirow{2}{*}{ Chi-Square } & \multirow{2}{*}{ P-value } \\
\hline & & $\mathbf{N}$ & $\%$ & $\mathbf{N}$ & $\%$ & & \\
\hline Gender & $\begin{array}{c}\text { Male } \\
\text { Female }\end{array}$ & $\begin{array}{l}13 \\
13\end{array}$ & $\begin{array}{l}13.0 \\
13.0\end{array}$ & $\begin{array}{l}40 \\
34\end{array}$ & $\begin{array}{l}40.0 \\
34.0\end{array}$ & 0.127 & 0.722 \\
\hline Residency & $\begin{array}{l}\text { outside city } \\
\text { inside city }\end{array}$ & $\begin{array}{c}8 \\
18\end{array}$ & $\begin{array}{c}8.0 \\
18.0\end{array}$ & $\begin{array}{l}14 \\
60\end{array}$ & $\begin{array}{l}14.0 \\
60.0\end{array}$ & 1.575 & 0.21 \\
\hline $\begin{array}{l}\text { Had received } \\
\text { education } \\
\text { program } \\
\text { regarding oral } \\
\text { mucositis }\end{array}$ & $\begin{array}{l}\text { Yes } \\
\text { No }\end{array}$ & 25 & 25.0 & 59 & $\begin{array}{l}59.0 \\
15.0\end{array}$ & 3.862 & 0.049 \\
\hline Age & $\begin{array}{c}<25 \\
25-35 \\
35 \geq\end{array}$ & $\begin{array}{c}6 \\
16 \\
4\end{array}$ & $\begin{array}{c}6.0 \\
16.0 \\
4.0\end{array}$ & $\begin{array}{c}6 \\
50 \\
18\end{array}$ & $\begin{array}{c}6.0 \\
50.0 \\
18.0\end{array}$ & 4.397 & 0.11 \\
\hline $\begin{array}{l}\text { Level of academic } \\
\text { qualification }\end{array}$ & $\begin{array}{l}\text { Preparatory } \\
\text { nursing } \\
\text { Diploma } \\
\text { Bachelor } \\
\text { Postgraduate }\end{array}$ & $\begin{array}{c}1 \\
22 \\
1 \\
2\end{array}$ & $\begin{array}{c}1.0 \\
22.0 \\
1.0 \\
2.0\end{array}$ & $\begin{array}{c}1 \\
45 \\
25 \\
3\end{array}$ & $\begin{array}{c}1.0 \\
45.0 \\
25.0 \\
3.0\end{array}$ & 9.368 & 0.025 \\
\hline $\begin{array}{l}\text { Years of } \\
\text { experience in } \\
\text { oncology field } \\
\text { Total }\end{array}$ & $\begin{array}{l}6-10 \\
11-15 \\
\geq 16\end{array}$ & $\begin{array}{l}1^{23} \\
2 \\
0 \\
26\end{array}$ & $\begin{array}{l}23.0 \\
1.0 \\
2.0 \\
0.0 \\
\mathbf{2 6 . 0}\end{array}$ & $\begin{array}{l}30 \\
34 \\
7 \\
3 \\
74\end{array}$ & $\begin{array}{l}30.0 \\
34.0 \\
7.0 \\
3.0 \\
\mathbf{7 4 . 0}\end{array}$ & 12.9 & 0.001 \\
\hline
\end{tabular}

Table 5. Association between Socio-demographic characteristics and mean of nurses' knowledge for oral mucositis of the oral

\begin{tabular}{|c|c|c|c|c|c|}
\hline Variables & Items & $\mathbf{N}$ & Mean & S.D & $\begin{array}{l}\text { Significant } \\
\text { Test }\end{array}$ \\
\hline \multirow{3}{*}{ Age } & $<25$ & 12 & 2.24 & 0.41 & $F=3.953$ \\
\hline & $25-35$ & 66 & 2.43 & 0.23 & P- \\
\hline & $35 \geq$ & 22 & 2.48 & 0.21 & value $=0.023$ \\
\hline \multirow[b]{2}{*}{ Gender } & Male & 53 & 2.43 & 0.28 & $\mathrm{~T}=0.4$ \\
\hline & Female & 47 & 2.41 & 0.25 & $\begin{array}{c}P- \\
\text { value }=0.69\end{array}$ \\
\hline
\end{tabular}




\begin{tabular}{|c|c|c|c|c|c|}
\hline \multirow{4}{*}{ Level of academic qualification } & $\begin{array}{c}\text { Preparatory nursing } \\
\text { school }\end{array}$ & 2 & 2.05 & 0.45 & \multirow{4}{*}{$\begin{array}{c}F=6.613 \\
P- \\
\text { value }=0.016\end{array}$} \\
\hline & Diploma degree & 67 & 2.39 & 0.28 & \\
\hline & Bachelor degree & 26 & 2.47 & 0.18 & \\
\hline & Postgraduate degree & 5 & 2.66 & 0.01 & \\
\hline \multirow{4}{*}{ Years of experience in oncology field } & $1-5$ & 53 & 2.34 & 0.32 & \multirow{4}{*}{$\begin{array}{c}F=3.502 \\
P- \\
\text { value }=0.01\end{array}$} \\
\hline & $6-10$ & 35 & 2.48 & 0.13 & \\
\hline & $11-15$ & 9 & 2.62 & 0.09 & \\
\hline & $\geq 16$ & 3 & 2.59 & 0.07 & \\
\hline \multirow[b]{2}{*}{ Residency } & inside city & 22 & 2.43 & 0.24 & \multirow{2}{*}{$\begin{array}{c}T=0.304 \\
P- \\
\text { value }=0.762\end{array}$} \\
\hline & outside city & 78 & 2.42 & 0.27 & \\
\hline \multirow{2}{*}{$\begin{array}{l}\text { Had received education program } \\
\text { regarding oral mucositis }\end{array}$} & Yes & 84 & 2.39 & 0.27 & \multirow{2}{*}{$\begin{array}{c}T=-2.604 \\
P- \\
\text { value }=0.011\end{array}$} \\
\hline & No & 16 & 2.57 & 0.08 & \\
\hline
\end{tabular}

Table 6. Represents the Nurses practice on oral mucositis

\begin{tabular}{|c|c|c|c|c|c|}
\hline knowledge for oral mucositis & No & $\begin{array}{l}\text { Not } \\
\text { sure }\end{array}$ & Yes & Mean \pm S.D & $\begin{array}{c}\text { Compara } \\
\text { tive } \\
\text { Sig. }\end{array}$ \\
\hline Do you teach the patients to use soft brush? & 7 & 2 & 91 & $2.84 \pm 0.53$ & Good \\
\hline $\begin{array}{l}\text { Do you teach the patients to brush teeth twice a day and } \\
\text { brush teeth more than two minutes? }\end{array}$ & 29 & 5 & 66 & $2.37 \pm 0.91$ & Good \\
\hline $\begin{array}{l}\text { Advice patients to use medicated mouth washes for oral } \\
\text { care? }\end{array}$ & 32 & 7 & 61 & $2.39 \pm 0.92$ & Good \\
\hline Advice patients take soft diet after chemotherapy? & 9 & 3 & 88 & $2.79 \pm 0.59$ & Good \\
\hline $\begin{array}{l}\text { Advice patient's Proper dental checkup before and after } \\
\text { chemotherapy? }\end{array}$ & 34 & 2 & 64 & $2.3 \pm 0.95$ & Fair \\
\hline $\begin{array}{l}\text { Do you use oral cryotherapy (ice bag) for } 30 \text { minutes before } \\
\text { bolus } 5 \text {-fluorouracil chemotherapy to prevent oral mucositis }\end{array}$ & 49 & 37 & 14 & $1.65 \pm 0.72$ & Poor \\
\hline $\begin{array}{l}\text { Sum } \\
\%\end{array}$ & $\begin{array}{c}160 \\
26.67\end{array}$ & $\begin{array}{c}56 \\
9.33\end{array}$ & $\begin{array}{c}384 \\
64.00\end{array}$ & $2.38 \pm 0.77$ & Good \\
\hline
\end{tabular}

Table 7. Association between Socio-demographic characteristics and mean of nurses' practice on mucositis of the oral cavity.

\begin{tabular}{|c|c|c|c|c|c|}
\hline Variables & Items & $\mathbf{N}$ & Mean & S.D & Significant Test \\
\hline \multirow{3}{*}{ Age } & $<25$ & 12 & 2.21 & 0.79 & \multirow{3}{*}{$\begin{array}{c}F=3.49 \\
P \text {-value }=0.034\end{array}$} \\
\hline & $25-35$ & 66 & 2.33 & 0.48 & \\
\hline & $35 \geq$ & 22 & 2.61 & 0.30 & \\
\hline \multirow{2}{*}{ Gender } & Male & 53 & 2.44 & 0.50 & \multirow{2}{*}{$\begin{array}{c}\mathrm{T}=1.222 \\
\mathrm{P} \text {-value }=0.225\end{array}$} \\
\hline & Female & 47 & 2.31 & 0.51 & \\
\hline \multirow{4}{*}{$\begin{array}{l}\text { Level of } \\
\text { qualification }\end{array}$} & $\begin{array}{l}\text { Preparatory nursing } \\
\text { school }\end{array}$ & 2 & 1.67 & 0.95 & \multirow{4}{*}{$\begin{array}{c}F=2.943 \\
P \text {-value }=0.037\end{array}$} \\
\hline & Diploma degree & 67 & 2.35 & 0.54 & \\
\hline & Bachelor degree & 26 & 2.39 & 0.36 & \\
\hline & Postgraduate degree & 5 & 2.83 & 0.12 & \\
\hline \multirow{4}{*}{$\begin{array}{l}\text { Years of experience in } \\
\text { oncology field }\end{array}$} & $1-5$ & 53 & 2.19 & 0.57 & \multirow{4}{*}{$\begin{array}{c}F=5.499 \\
P \text {-value }=0.001\end{array}$} \\
\hline & $6-10$ & 35 & 2.51 & 0.31 & \\
\hline & $11-15$ & 9 & 2.79 & 0.14 & \\
\hline & $\geq 16$ & 3 & 2.75 & 0.12 & \\
\hline \multirow{2}{*}{ Residency } & inside city & 22 & 2.37 & 0.52 & \multirow{2}{*}{$\begin{array}{c}T=-0.22 \\
P \text {-value }=0.982\end{array}$} \\
\hline & outside city & 78 & 2.3739 & 0.50 & \\
\hline \multirow{2}{*}{$\begin{array}{l}\text { Had received education } \\
\text { program regarding oral } \\
\text { mucositis }\end{array}$} & Yes & 84 & 2.3214 & 0.52 & \multirow{2}{*}{$\begin{array}{c}T=-2.433 \\
P \text {-value }=0.017\end{array}$} \\
\hline & No & 16 & 2.6458 & 0.27 & \\
\hline
\end{tabular}

Table (8): Correlation between Nurses' practice on mucositis of oral cavity and their level of knowledge, including knowledge about anatomy, pathology of oral cavity and

\begin{tabular}{lll}
\hline \multicolumn{1}{c}{ about anatomy, pathology of oral cavity and } & Nurses practice & $\begin{array}{l}\text { P- } \\
\text { value }\end{array}$ \\
\hline Variables & Correlation & $\mathbf{0 . 0 0 0}$ \\
\hline knowledge for anatomy of oral cavity & $\mathbf{0 . 7 1}$ & $\mathbf{0 . 0 0 0}$ \\
knowledge of general oral mucositis information. & 0.724 & $\mathbf{0 . 0 0 0}$ \\
knowledge for pathology of oral cavity & $\mathbf{0 . 5 7 5}$ & \\
\hline The level of significance at level 0.05 & & \\
Correlation : Spearman's rank correlation & & \\
\hline
\end{tabular}




\section{DISCUSSION}

This is a first study conducted in Sulaimani city to assess oncology nurses' knowledge and skills regarding oral mucositis among patients with cancer.

In the present study, the results showed that a large percentage of participants had good levels of knowledge in topics related to anatomy of oral cavity (64\%), Pathology of oral cavity with oral mucositis patients(73.59\%) and General Oral mucositis information were $(62.91 \%)$, these findings may referred to (84\%) of participants had received education program regarding oral mucositis. But our results are inconsistent with the observations of other researchers which suggested that nurses have inadequate knowledge regarding anatomy of oral cavity, Pathology of oral cavity with oral mucositis, oral health and $\mathrm{OM}$ assessment and management, leading to inadequate oral care of patients with cancer (Pai and Ongole, 2015; Abu Sharour, 2019).

In this study, a significant differences found between mean of nurses' knowledge for anatomy of oral cavity and level of academic qualification, years of experience in oncology field $(p<0.05)$. In addition to a significant association between nurses' knowledge of pathology of oral cavity with oral mucositis patients and nurses who had received education program regarding oral mucositis, level of academic qualification and Years of experience in oncology field $((p<0.05)$. But there were no significant association between nurses' knowledge of Anatomy, pathology of oral cavity with oral mucositis patients and age, residency and gender ( $p>0.05)$. While a significant differences were found between mean of nurses' knowledge for general oral mucositis information and age, level of academic qualification, years of experience in oncology field, in addition to those had received education program regarding oral mucositis $(p<0.05)$.

The results of the current study showed a statistically significant difference between level of academic qualification and level of knowledge of anatomy, pathology and general $\mathrm{OM}$ information, which is in line with other study conducted in Sudan(Ibrahim et al., 2015). Their results showed that nurses with a diploma had poorer knowledge and skills than those with a bachelor degree. In the USA, another study has revealed a positive correlation between level of education and level of knowledge regarding oral care (Grap et al., 2003). Such difference might be related to undergraduate preparation while in current study postgraduate degree had higher rank level of knowledge .

The results of the current study also showed that no significant differences were found among nurses' gender, age , residency, and anatomy and pathology knowledge. These findings in line with findings of Sinavarat et al., 2018 in Thailand, the majority of the participants was registered nurses and had similar undergraduate preparation and job description. In addition, $96.4 \%$ of them did not receive a continued education program regarding $\mathrm{OM}$ in their hospitals.

Moreover, $69.3 \%$ of the participants from the current study provided poor advice to patients regarding oral care and management. These findings supported previous results obtained by Araújo et al., 2015. Their findings indicated that $78.9 \%$ of staff nurses were unfamiliar with selfcare guidelines and lacked specific knowledge that should be provided to clients Araújo et al., 2015).

Years of experience and level of knowledge were correlated positively with the level of performance in the current study. These results were expected because knowledgeable and experienced nurses are competent in their performance. These results supported the previous studies (Lin et al., 2011; Labeau et al., 2008). Knowledge and experience can change the behavior and practices among the nurses toward $\mathrm{OM}$ care and management. Improving nurses' knowledge improves their oral care for patients with $\mathrm{OM}$.

In this study, there was a highly significant correlation between nurses' practice on mucositis of oral cavity and their level of knowledge about anatomy, pathology of oral cavity and knowledge of general oral mucositis, these findings disagree with another studies done in Khartoum by (Ibrahim et al., 2015) and in Ejypt by (Hassan, 2016), These differences may be related to our sample had good levels of knowledge in anatomy, pathology and general oral mucositis information, these knowledge positively affected on practice in $\mathrm{OM}$ in cancer patients.

\section{CONCLUSIONS}

Level of academic qualification, years of experience in the oncology field, age and receiving education program regarding oral mucositis affected directly on Nurses' knowledge and Practice about Oral Mucositis of Cancer Patients Undergoing Chemotherapy. Continuing education and training courses were recommended.

\section{ETHICAL CONSIDERATIONS COMPLIANCE WITH ETHICAL GUIDELINES}

This study was completed following the Declaration of Helsinki and approved by the College of Nursing and Medicine, University of Sulaimani, Sulaymaniyah, Iraq. The participants were informed about the research's purpose and ensured anonymity and confidentiality of the information. A written informed, voluntary participation consent was obtained from each participant.

\section{FUNDING}

This research did not receive any grant from funding agencies in the public, commercial, or non-profit sectors. 


\section{AUTHOR'S CONTRIBUTIONS}

Study concept: Hassan Husien Abdalla; Writing the original draft: Hadeel Abdulelah Ibrahim; Data collection: Data analysis: Hassan Husien Abdalla and Hadeel Abdulelah Ibrahim, Reviewing the final edition: All authors.

DISCLOSURE STATEMENT: The authors report no conflict of interest.

\section{ACKNOWLEDGEMENTS}

We thank the anonymous referees for their useful suggestions.

\section{REFERENCES}

Abu Sharour L (2019). A cross-sectional study on oncology nurses' knowledge and practice of oral mucositis among cancer patients in Jordan. Int J Nurs Sci; 6(3):283-287.

Al Ibraheemi AA, Shamoun S(2016). Incidence and risk factors of oral mucositis in patients with breast cancer who receiving chemotherapy in AlBashir hospital. Int J Hematol Oncol Stem Cell Res;10(4):217.

Araújo SN, Luz MH, da Silva G.R., Andrade EM, Nunes LC, Moura RO (2015). Cancer patients with oral mucositis: challenges for nursing care. Rev Latino-Am Enferm ;23(2):267-274.

Bray F, Ferlay J, Soerjomataram I, Siegel R , Torre L , \& Jemal A (2018). Global cancer statistics 2018: GLOBOCAN estimates of incidence and mortality worldwide for 36 cancers in 185 countries. A Cancer Journal For Clinicians; 0, 1-31.

Coolbrandt A, Wildiers H., Aertgeerts B, de Casterlé BD, van Achterberg T, Milisen K. (2018). Systematic development of CHEMO-SUPPORT, a nursing intervention to support adult patients with cancer in dealing with chemotherapy-related symptoms at home. BMC Nurs;17(1):28.

EOCC . Athena; (2018). EOCiCG, european oral care in cancer group oral care guidance and support.

Grap MJ., Munro CL, Ashtiani B, Bryant S(2003) . Oral care interventions in critical care: frequency and documentation. Am J Crit Care ;12(2):113118.

Hassan SS (2016). Knowledge and practices of critical care nurses regarding palliative care of cancer patients and suggestion for nursing guidelines booklet. Assiut Scientific Nursing Journal 4(8):103-122.

Ibrahim SM, Mudawi AM, Omer O (2015). Nurses' knowledge, attitude and practice of oral care for intensive care unit patients. Open J Stomatol ;5(7):179.
Kanagalingam J, Wahid MIA, Lin JC, Cupino NA, Liu E, Kang JH, etal., (2018). Patient and oncologist perceptions regarding symptoms and impact on quality-of-life of oral mucositis in cancer treatment: results from the Awareness Drives Oral Mucositis PercepTion (ADOPT) study. Support Care Canc ;26(7):2191-2200.

Lin YS, Chang JC, Chang TH, Lou MF(2011). Critical care nurses' knowledge, attitudes and practices of oral care for patients with oral endotracheal intubation: a questionnaire survey. J Clin Nurs ;20(21-22):3204-3214.

Labeau S, Vandijck D, Rello J, Adam S, Rosa A, Wenisch C, Dimopoulos G(2008). Evidence-based guidelines for the prevention of ventilatorassociated pneumonia: results of a knowledge test among European intensive care nurses. J Hosp Infect ;70(2):180-185.

Newton S, Hickey M, Brant J(2016). Elsevier Health Sciences; Mosby's oncology nursing advisor Ebook: a comprehensive Guide to clinical practice. Pai RR, Ongole R(2015). Nurses' knowledge and education about oral care of cancer patients undergoing chemotherapy and radiation therapy. Indian J Palliat Care ;21(2):225

Sinavarat $P$, Manosoontorn S, Anunmana C(2018). Knowledge, attitudes, and behavior towards oral health among a group of staff caring for elderly people in long-term care facilities in Bangkok, Thailand. Mahidol Dent J ; 38(1):23-38

Southern H (2007). Oral care in cancer nursing: nurses' knowledge and education. J Adv Nurs ;57(6):631-638.

Sung L, Robinson P, Treister N, Baggott T, Gibson $P$, Tissing W, etal., (2015). Guideline for the prevention of oral and oropharyngeal mucositis in children receiving treatment for cancer or undergoing haematopoietic stem cell transplantation. BMJ Support Palliat Care. 2015 bmjspcare-2014-000804

Tranmer R, Boyd L, Johnson T, Howlett B, Bowen $D$, Peterson $T(2013)$. National survey of oncology members' knowledge, education and patient management regarding oral care in cancer therapy. Health Interprofessional Pract; 2(1):6. ]

Worthington HV, Clarkson JE, Eden TO (2007).Interventions for preventing oral mucositis for patients with cancer receiving treatment. Cochrane Database Syst Rev. 2007;17(4):CD000978. 